\title{
Geçici Koruma Altındaki Suriyelilerin Türkiye Ekonomisine Etkisi: Denizli Örneği*
}

\author{
Özay ÖZPENÇE 1 , Emine ÇELİK ${ }^{2}$ \\ Özet
}

Mart 2011'de Suriye'de meydana gelen savas neticesinde ülkelerini terk edip komșu ülkelere sığınan Suriyelilerin en çok tercih ettiği ülkelerden biri de Türkiye'dir. Savaşın uzun süre devam etmesinin de etkisiyle ülkemizde hızla artan Suriyeli sayısı sosyal, siyasal, ekonomik ve kültürel olarak birçok açıdan ülkemizi etkilemiștir. Bu çalışmamızda tekstil şehri olarak bilinen Denizli iline sığınan geçici koruma altındaki Suriyelilerin Denizli'ye etkileri ekonomik yönden analiz edilmiștir. Çalıșmamızın sonucunda, Suriyelilerin olumsuz vergi algısına neden olduğu ortaya çıkmıștır. Bununla beraber kamu harcamalarını, kayıt dışılığı ve işsizliği artırdığı sonucuna ulaşılmıştır. Ayrıca kadınların ve eğitim seviyesi yüksek olan katılımcıların Geçici Koruma Altındaki Suriyelilerin çalışma hayatına katılımlarını daha çok destekledikleri tespit edilmiştir.

\section{Anahtar kelimeler: Geçici Koruma Altındaki Suriyeliler, Göç, Denizli, Ekonomik Etki, Suriye Jel Kodu: R23, C83, H76}

\section{The Impact of Syrians Under Temporary Protection on The Turkish Economy: Denizli Case Abstract}

Turkey is one of the most preferred countries for Syrian people who abandoned their country and moved into several neighbor countries, because of Syrian civil war which occurred in March 2011. With the impact of the war for a long time, the number of Syrians who have increased rapidly in Turkey has influenced Turkey in many ways as social, political, economic, and cultural. In this research, the impacts of the Syrians under temporary protection in Denizli, known as textile city, were analyzed economically. As a result of research, it was revealed that Syrians caused negative tax perception. However, concluded that public expenditures informality and, unemployment increased. In addition, it was determined that women and those with a high level of education more supported the participation of Syrians in the working life.

Keywords: Under Temporary Protection of Syrians, Migration, Denizli, Economic Effect, Syria.

Jel Codes: R23, C83, $H 76$

\section{GíRiş}

İnsanlık tarihinin en önemli unsurlarından biri olan ve aynı zamanda karmaşı bir yapıya sahip olmakla beraber çok eski dönemlere dayanan göç olgusu; kıtadan kıtaya, ülkeden ülkeye insanların yer değişikliğine neden olmaktadır. Bununla birlikte gidilen ülkeyi ekonomik, sosyal, siyasal, kültürel açllardan değişime uğratıp etkilemektedir.
Mart 2010'da Tunus'ta bir gencin kendisini pazar yerinde yakmasıyla başlayan Arap Baharı birçok ülkeyi etkilemiştir. Bu ülkelerden biri olan Suriye, Arap Baharı'ndan en çok etkilenen ülkelerden biri olmuştur. Farklı birçok dini, mezhebi ve irkı bünyesinde barındırdığından dolayı Suriye'de bu etki büyüyerek sonu gelmeyen bir savaş ortamının oluşmasına neden olmuștur. Suriye'de oluşan bu kaos ortamı dünya genelini etkileyerek İkinci Dünya

ATIF ÖNERİSi (APA): Özpençe, Ö., Çelik, E. (2021). Geçici Koruma Altındaki Suriyelilerin Türkiye Ekonomisine Etkisi: Denizli Örneği. İzmir İktisat Dergisi. 36(2). 423-437. Doi: 10.24988/ije.202136212

*Çalışma, Pamukkale Üniversitesi, Sosyal Bilimler Enstitüsü'nde 21.08.2019 tarihinde savunulan Yüksek Lisans tezinden yararlanılarak oluşturulmuştur.

1 Doç.Dr., Pamukkale Üniversitesi, İktisadi ve İdari Bilimler Fakültesi, DENİZLİ,

EMAIL: oozpence@pau.edu.tr ORCID:0000-0003-1502-3240

${ }^{2}$ Y.Lisans, Pamukkale Üniversitesi, Sosyal Bilimler Enstitüsü, DENIZLİ,

EMAIL: emine.celik.563@gmail.com ORCID:0000-0002-2951-1416 


\section{Ö. ÖZPENÇE - E. ÇELIK}

Savaşı'ndan sonraki en büyük mülteci krizi olarak adlandırılmıştır.

Savaşın giderek büyümesi sonucunda ülkelerini terk etmek zorunda kalan Suriyeliler; Türkiye ile komşu olması ve Türkiye'nin açık kapı politikası uygulamasından dolayı ülkemize yoğun bir şekilde göç etmişlerdir. Bunun sonucunda Türkiye 2014 yılından itibaren en çok mülteci kabul eden ülke konumuna gelmiştir.

Suriye'de yaşanan bu olaydan en çok etkilenen ülke olan Türkiye'de 2019 yılı itibariyle Suriyeli sayısı 3.646.889'a ulaşmıştır. Yıllar itibariyle artan bu sayının da etkisiyle Suriyelilere2014'te yürürlüğe giren Yabancllar ve Uluslararası Koruma Kanunu'nun 91. Maddesinde Geçici Koruma Statüsü verilmiștir. Geçici Koruma Statüsü altındaki Suriyelilerin sayısının her geçen gün artması siyasi, sosyal, kültürel, ekonomik birçok soruna yol açmıştır. Ülkemizi ise en çok ekonomik yönden etkilemişlerdir (İçişleri Bakanlığı Göç İdaresi Genel Müdürlüğü,2019).

Bu çalışmanın amacı, Denizli iline sığınan geçici koruma altındaki Suriyelilerin Denizli'ye etkilerini ekonomik yönden saptamaktır. Suriyelilerle ilişkilendirilebilecek vergi algısı, kamu harcamaları artışı, kalabalıklaşma maliyeti, kayıt dışılık ve işsizlik, çalışma hayatına katılımları, yardımların yeterliliği ve enflasyona etkilerini gösterebilmek hedeflenmiştir. Ayrıca göç üzerine yapılacak olan çalışmalara ve mültecilerin ekonomiye etkilerine yönelik diğer çalışmalara katkı sağlanması hedeflenmiştir.

Çalışma üç ana bölümden oluşmaktadır. Birinci bölümde göçün tanımına, tarihine ve göçün sebeplerine yer verilmiș, daha sonra da mülteci ve sığınmacı kavramları açıklanmıștır. Bununla birlikte dünyada meydana gelen önemli göç olaylarına yer verilmiştir. Ardından Suriye'de meydana gelen olaylar anlatılarak savaşın nedenleri açılkanmıştır. İkinci bölümde, Türkiye ve Denizli'deki Suriyelilerin durumuna değinilerek ekonomiye etkilerinden, ülkemizdeki statülerinden ve yapılan yardım politikalarından bahsedilmiştir. Üçüncü bölümde ise, Denizli'de yașayan Geçici Koruma Altındaki Suriyelilerin Denizli ekonomisine etkisi analiz edilmiştir ve Suriyelilerin kayıt dışılığa, işsizliğe, vergi algısına, kamu harcamalarına etkisi ortaya konularak çalışma hayatına katılımlarının ne yönde olması gerektiğine yer verilmiştir. Son olarak araştırma sonuçlarına göre genel bir değerlendirme yapılmıştır.

\section{KAVRAMSAL ÇERÇEVE}

\subsection{Göç}

Göç konusunda yapılan sayısız araştırma bulunmaktadır. Literatür taraması yapıldı̆̆ında göç olgusu; evreni şekillendirmede büyük öneme sahip tarihsel bir güç olarak adlandırılırken diğer taraftan insan davranışının vazgeçilmez bir parçası olarak literatüre geçmiştir. Bununla birlikte göç hakkındaki iddialı cümlelerden biri de göç olgusunun tarih kadar eski bir olay olduğudur. Lakin bu ifadelere rağmen göçün net bir tanımı yapılıp nedenleri ve etkileri net bir şekilde ortaya konamamaktadır. Göçün ilk olarak hangi tarihte gerçekleştiğine dair kesin bir kanit bulmak zordur. Fakat zamanla dünyanın her köșesinde gözlemlendiği bilinen bir gerçektir (IOM, 2017:7; IFFRC,2017:3).

Göç; istila, fetih, silah zoruyla yerinden etme, doğal afetlerden kaçma, sömürge haline gelme, kölelik gibi çok farklı nedenlerden dolayı insanların bir yerden bir yere gitmesini tanımlamak için kullanılan bir olgudur. Diğer bir tanıma göre ise göç; çok eski dönemlerde organizma ve çevre arasındaki yakın ilişkinin mükemmel bir örneği olarak ifade edilmiștir. Ayrıca birçok biyolog göç kelimesini, tüm nüfusun uzun mesafeler boyunca "kahramanca" göstermiş olduğu hareket olarak ifade etmiștir. Aynı zamanda göç kavramını "ya uluslararası sınırlar arasında yada bir devletin sınırları içindeki hareket süreci" olarak tanımlayan araştırmalarda bulunmaktadır. Bu hareketin sebebi ne olursa olsun mültecilerin, yerinden edilmiş insanların ve ekonomik göçmenlerin davranışları, yer değiştirmeleri göç olgusu içinde yer almaktadır (Dıngle and Drake, 
2007: 113; Cornelius vd., 2013:47; IOM, 2017:7; IFRC, 2017:2).

Göç üzerine yapılan çalışmalara bakıldığında; William Farr'ın, göçün herhangi bir kesin yasaya bağlı olmaksızın yürüdüğünü savunması üzerine Ravenstein'in (1885) de ilgisinin bu konu üzerine yoğunlaştığ görülmüștür. $\mathrm{Bu}$ yoğunlaşmanın sonucu olarak Ravenstein, William Farr'ın yaptığı çalışmanın aksini iddia etmiştir ve bu çalışma 1885'te yayınlanarak göçle ilgili olarak yapılan ilk çalışma özelliğine sahip olmuştur (Ravenstein,1885; Çağlayan, 2006: 69).

\subsection{Mülteci}

1951 Sözleşmesi, mültecilere ilişkin daha önceki uluslararası belgeleri pekiştirmekte ve mültecilerin uluslararası düzeyde haklarının en kapsamlı biçimde sinıflandırılmasını sağlamaktadır. Belirli mülteci gruplarına uygulanan daha önceki mülteci belgelerinin aksine 1951 Sözleşmesi'nin 1. Maddesinde "mülteci" teriminin tek bir tanımı onaylanmıştır. Bu tanımın vurguladığı nokta ise kişilerin siyasi zulümden ve diğer zulümlerden korunması gerektiğidir. Bu sözleşmeye göre "mülteci; ırk, din, uyrukluk, belirli bir toplumsal gruba üyelik veya siyasi nedenlerden dolayı zulmeuğrama korkusu nedeniyle menşe ülkelerine geri dönmek istemeyen kişidir" şeklinde tanımlanmıștır (UNHCR,2010:3).

1951 tarihli sözleşme, o tarihte meydana gelmiş olaylar veya daha öncesinde meydana gelen olaylar sonucunda mülteci olanları kapsamaktaydı. Zaman geçtikçe yeni mülteci durumlarının ortaya çıkmasıyla beraber yeni mültecilere 1951 Sözleşmesinin hükümlerinin uygulanabilir hale getirilmesi ihtiyacı doğdu. Sonuç olarak mültecilerin statüsüyle ilgili bir protokol hazırlandı. Birleşmiş Milletler Genel Kurulunda değerlendirildikten sonra 4 Ekim 1967'de yürürlülüğe girdi (UNHCR, 1992:3).

\section{Protokolü'nün 1951 Cenevre} Konvansiyonu ile arasındaki farklar göz önünde bulundurulduğunda, Mültecilerin Hukuk Statüsüne İlişkin 1967 Protokolü'nün 1. maddesinde Ocak 1951 tarih kısitlamasına bakılmaksızın mültecilerin eșit hukuki statüden yararlanmalarının sağlanacağı belirtilmiştir ve aynı zamanda bu protokolün hiçbir coğrafi sınırlama yapılmaksızın uygulanacağı ifade edilmiştir.

\subsection{Suriye'de Gerçekleşen Olaylara Bakış}

Suriye'nin 1946'da bağımsız olmasından bu yana, 1970 yılında Hafız Esad iktidara gelene kadar başa gelen hükümetlerin ömrü bir yıldan azdı. Esad'in iktidara gelmesiyle beraber Suriye'de siyasi istikrar sağlanmıştır. SSCB ve İran ile yakın ilişkiler kuran Esad halkla fazla bağlantı kurmamayı tercih etmiştir. 2000 yılında ise Hafız Esad'ın oğlu Beşar Esad başkan olmuştur (Haran, 2016:2).

Suriye, jeopolitik konumundan dolayı birçok farklı gücün dikkatini çekerek yabancı güçlerin savaş alanı haline gelmiştir. Birinci Dünya Savaşı'ndan sonra sömürgeci devletlerin kullandığı en önemli politika önce parçala daha sonra da yönet anlayışına dayanmaktaydı. Özellikle Fransa, Suriye'nin mezhep ve etnik köken bakımından farklılıklarını kullanarak sürekli Suriye vatandaşlarını birbirine karşı kışkırtma yoluna gitmiştir (Nassar, 2013 ; Budak vd., 6).

2010 yllına gelindiğinde ise Tunus'ta, 26 yaşındaki Muhammed Buazizi'nin kendisini pazar yerinde yakması sonucunda Tunus halkının ayaklanmasıyla başlayan Arap Baharı'ndan etkilenen ülkelerin başında birçok farklı dini, ırkl, mezhebi bir arada barındıran Suriye gelmektedir. Arap halkının özgürlük arayışıyla başlayan olay birçok ülkeyi etkilemiştir. Diğer ülkelerde yönetim değişikliğiyle son bulan bu olay Suriye'de sonu gelmeyen bir savaş ortamına dönüşmüștür (Karkın ve Yazıcı, 2015:202-203).

Suriye'de Mart 2011'de başlayan bu çatışma kısa sürede uluslararası aktörlerin yer aldığı bir iç savaşa dönüşmüştür. Çatışmadan etkilenenlerin büyük çoğunluğu (tüm mültecilerin \%76'sı) Suriye'ye komşu ülke olan Türkiye, Lübnan, Ürdün, Irak ve az sayıda da olsa Mısır'a göç etmişlerdir. Ekim 2011'de Türkiye'deki yetkili makamlar Suriye'den 
gelen tüm Suriyeliler için geçici bir koruma rejiminin yürürlüğe gireceğini ilan etmişlerdir (De Bel-Air, 2016:1).

\subsection{Türkiye'deki Suriyelilerin Yasal Statüsü ve Sayısı}

22 Ekim 2014'te Türkiye Cumhuriyeti Bakanlar Kurulu, Yabancllar ve Uluslararası Koruma Kanunu'nun 91. Maddesine göre geçici koruma hakkında bir yönetmelik yayınlamıștır. $\mathrm{Bu}$ Geçici Koruma Yönetmeliğinin 1. Maddesi Suriye vatandaşlarının yanı sıra Suriye'den gelen vatansız kişileri ve mültecileri de kapsamaktadır. $\mathrm{Bu}$ yönetmelik, Bakanlar Kurulu tarafından hazırlanmıștır ve bu yönetmelikle birlikte savaştan dolayı ülkelerini terk etmek zorunda kalan mülteci ve şartlı mülteci durumunda bulunmayan Suriyelilerin yasal statüsü ifade edilmiștir. Bu yönetmeliğe göre ülkemizdeki Suriyeliler "Geçici Koruma" statüsüne sahip olmuşlardır. Göç İdaresi Genel Müdürlüğü'ne kayıt için bașvuran geçici koruma altındakilerin sosyal yardım, sağlık, eğitim, çalıșma izni gibi hak ve hizmetlerden yararlanabileceği belirtilmiștir (UNHCR, www.fluechtlingshilfe.ch ; Topal, 2015: 14-15).

Mart 2011'den beri Suriye'de devam eden çatışmalardan bu yana ülkemizde her geçen gün Suriyeli sayısı artmaktadır. Așağıda yer alan Tablo 1'de Suriyelilerin sayısındaki değişim savaşın başladığı yıldan günümüze kadar gösterilmiştir.

Tablo 1: Yıllara Göre Geçici Koruma Altındaki Suriyelilerin Sayısı

\begin{tabular}{|c|c|}
\hline $\mathbf{2 0 1 1}$ & 0 \\
\hline $\mathbf{2 0 1 2}$ & 14.237 \\
\hline $\mathbf{2 0 1 3}$ & 224.655 \\
\hline $\mathbf{2 0 1 4}$ & 1.519 .286 \\
\hline $\mathbf{2 0 1 5}$ & 2.503 .549 \\
\hline $\mathbf{2 0 1 6}$ & 2.834 .441 \\
\hline $\mathbf{2 0 1 7}$ & 3.426 .786 \\
\hline $\mathbf{2 0 1 8}$ & 3.623 .192 \\
\hline $\mathbf{2 0 1 9}$ & 3.646 .889 \\
\hline
\end{tabular}

Kaynak: İçişleri Bakanlığı Göç İdaresi Genel Müdürlüğü, 2019

\subsection{Geçici Koruma Altındaki Suriyelilerin Türk Ekonomisi ve İstihdamına Etkileri}

Suriyelilerin ekonomimize en önemli etkilerinden biri kamu bütçesinden Suriyeliler için yapılan harcamalardır. Aşağıda yer alan tablo 2' de Bakanlıkların ve diğer kamu kurumlarının Suriyeliler için yapmış olduğu harcamalar ayrıntılı bir șekilde verilmiştir.

Tablo 2:Türkiye'deki Bakanlık ve Diğer Kamu Kurumlarının Suriyelilere Yaptığı Harcamalar

\begin{tabular}{|c|c|}
\hline \multirow{2}{*}{\multicolumn{2}{|c|}{$\begin{array}{c}\begin{array}{c}\text { Bakanlık ve Diğer Kamu Kurumlarının } \\
\text { Suriyelilere Yaptığı Harcamalar }\end{array} \\
2015 \text { Yılı Bütçesi }\end{array}$}} \\
\hline & \\
\hline Maliye Bakanlığı & 1.136 .983 .000 \\
\hline Hazine Müsteşarlığı & 71.292 .000 \\
\hline Milli Eğitim Bakanlığı & 46.243 .000 \\
\hline Milli Savunma Bakanlığı & 32.102 .000 \\
\hline $\begin{array}{llll}\text { Çalıșma ve } & \text { Sosyal Güvenlik } \\
\text { Bakanlı̆̆ı } & & & \\
\end{array}$ & 30.725 .000 \\
\hline Ara Toplam & 1.315 .000 .000 \\
\hline \multicolumn{2}{|c|}{ 2011-2015 Harcamaları } \\
\hline $\begin{array}{l}\text { Ulaştırma, Denizcilik ve } \\
\text { Haberleşme Bakanlığı }\end{array}$ & 21.689 .000 \\
\hline Aile ve Sosyal Politikalar Bakanlığı & 18.400 .000 \\
\hline $\begin{array}{l}\text { Tarım Gıda ve Hayvancılık } \\
\text { Bakanlığı }\end{array}$ & 14.793 .000 \\
\hline Emniyet Genel Müdürlüğü & 12.174 .000 \\
\hline Orman ve Su İşleri Bakanlığı & 11.973 .000 \\
\hline Kamu Hastaneleri Kurumu & 9.876 .000 \\
\hline İçişleri Bakanlığı & 9.443 .000 \\
\hline Adalet Bakanlığı & 8.029 .000 \\
\hline Halk Sağlığı Kurumu & 7.643 .000 \\
\hline Gençlik ve Spor Bakanlığı & 7.275 .000 \\
\hline Jandarma Genel Komutanlığı & 7.089 .000 \\
\hline Sağlık Bakanlığı & 3.706 .000 \\
\hline Diyanet İşleri Başkanlığı & 3.447 .000 \\
\hline Bilim, Sanayi ve Teknoloji Bakanlığı & 3.327 .000 \\
\hline Kültür ve Turizm Bakanlığı & 2.691 .000 \\
\hline AFAD Başkanlığı & 2.573 .000 \\
\hline Ara Toplam & 140.000 .000 \\
\hline Toplam & 1.451 .000 .000 \\
\hline
\end{tabular}

Kaynak: Erdoğan ve Ünver, 2015: 39.

Aşağıda yer alan Tablo 3'de gösterildiği gibi, 2011-2015 yıllarında ülkemizin Geçici Koruma Altındaki Suriyeliler için iç kaynaklar ve dış kaynakların yaptığı toplam harcamalar 
7.158.250.458 ABD Doları, yaklaşık olarak 20 Milyar TL'yi geçtiği belirtilmektedir.

Tablo 3: 2011-2015 Ylllarl Arasinda Suriyelilere Yapılan Harcamaların Kaynakları

\begin{tabular}{|c|c|}
\hline \multicolumn{2}{|c|}{$\begin{array}{l}\text { 2011-2015 Yılları Arasında Suriyelilere Yapılar } \\
\text { Harcamaların Kaynakları }\end{array}$} \\
\hline Harcama Kaynağı & USD \\
\hline \multicolumn{2}{|l|}{ İç Kaynaklar } \\
\hline Türkiye Cumhuriyeti & 6.458 .428 .396 \\
\hline $\begin{array}{ll}\text { Sivil Toplu } & \text { Kuruluşları } \\
\text { Harcamaları } & \\
\end{array}$ & 294.955 .947 \\
\hline $\begin{array}{l}\text { Türk Yerel Yönetimleri, Diyanet } \\
\text { Vakfı ve Kızılay }\end{array}$ & 77.380 .170 \\
\hline Toplam (İç Kaynak) & 6.830 .764 .513 \\
\hline \multicolumn{2}{|l|}{ Diş Kaynaklar } \\
\hline $\begin{array}{ll}\text { BM } & \text { Kuruluşlarının } \\
\text { Bağışları(UNHCR, } & \text { UNICEF, IOM, } \\
\text { WFP, UNFP) } & \\
\end{array}$ & 328.389 .702 \\
\hline $\begin{array}{llr}\text { Avrupa } & \text { Ülkeleri, Yabancı Sivil } \\
\text { Toplum Kuruluşları ve Diğer } \\
\text { Ülkeler }\end{array}$ & 89.096 .268 \\
\hline Toplam (Diş Kaynak) & 417.485 .970 \\
\hline Genel Toplam & 7.158 .250 .458 \\
\hline
\end{tabular}

Kaynak: Erdoğan ve Ünver, 2015: 40.

Tablo 4: 5 Aralık 2017 tarihi ile Suriyeliler için Katlanılan Toplam Maliyet

\begin{tabular}{|l|l|}
\hline $\begin{array}{l}\text { Harcama Kaynağı/Harcama } \\
\text { Türü }\end{array}$ & TL \\
\hline AFAD & 5.586 .594 .000 \\
\hline $\begin{array}{l}\text { Güvenlik ve Kamu Düzeni } \\
\text { Hizmetleri }\end{array}$ & 9.228 .707 .000 \\
\hline Sağlık Hizmetleri & 16.030 .111 .000 \\
\hline Eğitim Hizmetleri & 15.489 .968 .000 \\
\hline Belediyecilik Hizmetleri & 17.527 .481 .000 \\
\hline $\begin{array}{l}\text { Türk Kızılay'ı, Çeşitli } \\
\text { Vakıflar }\end{array}$ & 2.058 .122 .000 \\
\hline $\begin{array}{l}\text { Belediyeler Tarafından } \\
\text { Düzenlenen Kampanyalar }\end{array}$ & 312.092 .000 \\
\hline $\begin{array}{l}\text { Kamplardaki Amortisman } \\
\text { Maliyeti }\end{array}$ & 1.505 .386 .000 \\
\hline $\begin{array}{l}\text { Göç İdaresi Genel } \\
\text { Müdürlüğü }\end{array}$ & 780.807 .000 \\
\hline $\begin{array}{l}\text { Diğer sivil toplum } \\
\text { kuruluşlarının kayıtlı proje } \\
\text { bazlı yardımları }\end{array}$ & 852.600 .000 \\
\hline Vatandaş Yardımı & 11.649 .434 .000 \\
\hline Fırat Kalkanı Bölgesinden & 1.630 .457 .000 \\
\hline Sıfır Noktası İnsani Yardım & $2,228,775,000.00$ \\
\hline Toplam & $84,880,534,000 \mathrm{TL}$ \\
\hline
\end{tabular}

Kaynak: 21. Yüzyıl Türkiye Enstitüsü, 2020:13.

Suriyelilerin kamu harcamalarındaki artışa etkisi değerlendirildiğinde, karşımıza nüfus artışıyla beraber artan kamu hizmetleri çlkmaktadır. Böylelikle kentsel yatırım maliyetleriyle birlikte alt yapı sorunları da artmakta ve daha fazla kamusal hizmete duyulan ihtiyaç kamu harcamalarının da artışına sebep olmaktadır. Aynı zamanda eğitim, sağlık gibi yarı kamusal mallara olan ihtiyacın artmasiyla beraber devlet bütçesine büyük bir yük dahil edilmektedir. $\mathrm{Bu}$ yükün vergilerle finanse edilme durumunun ortaya çıkması ve Suriyelilerin vergi ödeme konusunda yetersiz kalmasından dolayı bu açık vatandaşlarımızın ödediği vergilerle kapatılmaya çalışılmaktadır (WellCommunities, 2018: 60-61).

Tablo 4'te görüldüğü gibi, 5 Aralık 2017 tarihi ile Geçici Koruma Altındaki Suriyeliler için yapilan toplam harcamalar 84,880,534,000 olarak hesaplanmıştır.

\subsection{Geçici Koruma Altındakilere Yönelik Yardım Politikaları}

Afet ve Acil Durum Yönetimi Başkanlığg Bütçesi'ne (cari transferler ekonomik kodu) yapılan aktarmalar, geçici koruma altındaki Suriyelilerin eğitim, sağlık, kalacak yer ve beslenme yönünden iyileştirilmeleri için kullanılmaktadır.2017 için bu miktar 1.470.000.000 (TL)'dir (Maliye Bakanlığı, 2018:173).

2012 Kasım ayından itibaren Geçici Koruma Altındaki Suriyelilerin ihtiyaçlarını karşılayabilmesi için KIZILAYKART çıkartılmıştır ve 90.666 yararlanıcı bulunmaktadır. Yükleme yapılan kart sayısı 19.657'dir.Toplam yükleme tutarı ise 574 milyon TL'dir. Bu program ilk kez Ekim 2012'de Kilis'te uygulanmıştır ve Aralık 2014'te 21 kampta hizmet verilmeye bașlanmıștır. 2017 Mayıs ayında hizmet veren merkez sayısı 18 olmuştur (Türk Kızılay Göç Hizmetleri Direktörlüğü, 2019).

Aşağıda yer alan Tablo 5'te Suriyelilerin ve diğer tüm yabancıların faydalanabildiği bir yardım programı olan Sosyal Uyum Yardım Programı'na aktarılan kaynak ve kişi sayısı gösterilmiștir. 
Tablo 5: Yabancılara Yönelik Sosyal Uyum Yardım Programına Aktarılan Kaynak

\begin{tabular}{|c|c|c|}
\hline Yıl & Aktarılan Kaynak (Bin TL) & Kişi Sayısı \\
\hline 2016 & 391.300 & 589 \\
\hline 2017 & 1.067 .000 & 199.336 \\
\hline 2018 & 2.117 .000 & 261.303 \\
\hline
\end{tabular}

Kaynak: T.C. Aile ve Sosyal Politikalar Bakanlığı, 2016: 60; T.C. Aile, Çalışma ve Sosyal Hizmetler Bakanlığı, 2018:150.

Tablo 6'da hem Suriyelilere hem de diğer yabancılara yönelik uygulanan Şartlı Eğitim Yardımı'na aktarılan kaynak ve yararlananlarin mevcut sayısı gösterilmektedir.

Tablo 6: Yabancılara Yönelik Şartlı Eğitim Yardımına Aktarılan Kaynak

\begin{tabular}{|c|c|c|}
\hline Yıl & Aktarılan Kaynak (Milyon TL) & $\begin{array}{c}\text { Kişi } \\
\text { Sayısı }\end{array}$ \\
\hline 2017 & 32 & 92.024 \\
\hline 2018 & 175 & 173.073 \\
\hline
\end{tabular}

Kaynak: T.C. Aile, Çalışma ve Sosyal Hizmetler Bakanlığı, 2018: 151.

\subsection{Geçici Koruma Altındaki Yabancılar İçin Çalışma İzni}

Yabancıların çalışma durumlarına ilişkin bilgi hukukumuzda birçok kanunda yer almaktadır. İlk olarak 1982 Anayasası'nda belirtilen bu çalışma özgürlügü Yabancllar ve Uluslararası Koruma Kanunu'nda ve Uluslararası İşgücü Kanunu'nda düzenlenmiştir (Aslantürk ve Tunç, 2018:153).

Tablo 7'deki 2017 yılı verileri göz önünde bulundurulduğunda ülkemizde 3,5 milyonu aşkın Suriyeli yaşamasına rağmen sadece 20.966 Suriyelinin çalışma iznine sahip olması kayıt dışı istihdamın önüne geçilemediğini ve geriye kalan birçok Suriyelinin hala kayıt dışı bir şekilde çalıștığını göstermektedir. Aynı zamanda bu durum 2016 yılında işleve konulan çalışma izni uygulamasının tam olarak işlevini gösteremediğini de ortaya koymaktadır.

Tablo 7: Çalışma İzni Verilen Suriyeli Sayısı ve Cinsiyet Dağılımı 2017

\begin{tabular}{|c|c|c|c|}
\hline Ülke & Kadın & Erkek & Toplam \\
\hline Suriye & 1.641 & 19.327 & 20.966 \\
\hline
\end{tabular}

Kaynak: T.C. Aile, Çalışma ve Sosyal Hizmetler Bakanlığı, 2017.

\subsection{Denizli'deki Suriyelilerin Nüfusu ve Genel Durumu}

Denizli ilimizde Geçici Koruma altındaki Suriyeli sayısı 2017 Aralık ayında 10.205 iken 21 Şubat 2019 yılı itibariyle bu sayı 12.660'a yükselmiştir (İçişleri Bakanlığı Göç İdaresi Genel Müdürlüğü, 2019).

Denizli ili uluslararası piyasalardaki konumundan dolayı 2010 yılından itibaren İran, Afgan, Suriyeli mültecilere ev sahipliği yapmaktadır. Denizli iş gücü piyasası incelendiğinde ise Suriyelilerin ikincil iş gücü piyasasında yer aldığı tespit edilmiştir. Daha çok emek yoğun işlerde tercih edilen Suriyeliler temel ihtiyaçlarını karşılayabilmek için düşük ücretlere ve uzun çalışma saatlerine razı gelmektedir (Akbaş ve Ulutaş, 2018:188).

\subsection{Göçün Ekonomiye Etkisi Üzerine Yapılmış Benzer Çalışmalar}

1990'lı yıllardan beri yapılmış olan birçok akademik çalışma, göçün ABD'nin yerli çalışanlarının kazançlarını ne ölçüde etkilediğini ortaya koymaya çalıșmıştır. $\mathrm{Bu}$ çalışmaların bulguları çok farklı olmasına rağmen (bazıları göçün yerli çalışanları etkilediği sonucuna varırken bazıları ise hiçbir etkisinin olmadığını öne sürmüş) uzlaşmaya varılmaya çalışılmıştır. Fakat göçün; yetenekleri kısıtlı, eğitim seviyesi düşük olan kişilerin ve yerel işçilerin ücretlerini azalttığı diğer seçeneğe göre daha olasıdır. Bu konu hakkında yapılmıș en kapsamlı çalıșmalardan biri Pia M. Orrenius ve Madeline Zavodny'nin Ağustos 2003 tarihli raporudur. $\mathrm{Bu}$ araştırmanın sonucuna göre göçmen oranındaki artışın ücretler üzerinde önemli derecede bir olumsuz etkisinin olmadığı ortaya konulmuştur (Anrıg, 2004, https://tcf.org).

Yeni Zelanda'da göçün genel ekonomik etkisinin incelendiği en kapsamlı çalışmalardan biri Poot ve diğerleri (1988) tarafindan yapılmıștır fakat Avustralya ve ABD'de yapılan çalışmalarla aynı büyüklükte değildir ve iş gücü piyasasını da kapsamaktadır (Poot and Cochrane, 2004:4). 
2012 yılında Chmura Economics\& Analytıcs tarafından hazırlanan rapora göre; 2006'dan beri Cleveland bölgesinde mültecilerin bölgeye ekonomik etkilerinin arttığı gözlemlenmiștir. Amerika'ya göç eden mülteciler için önemli bir yer olan Cleveland bölgesindeki mülteci sayısının artış göstermesiyle beraber yerel yönetimlerin vergi gelirlerinde artış meydana gelmiştir. Aynı zamanda yerel konut ve yerel olarak üretilen mal ve hizmetlere olan talep artmıştır ve bölgesel ekonomi canlılık kazanmıștır. Rapora göre; gelişmiş ülkelerde mültecilerin hayatlarına adapte olduktan sonra bölgesel düzeyde ve uzun vadede ișgücüne ve ekonomik kalkınmaya önemli katkılarının olduğu belirtilmiştir (Chmura Economics\& Analytıcs, 2012: 27-32).

Ülkemizde 2016' da yapılan bir diğer çalışmada ekonomimiz için hem firsatı hem de riski beraberinde getiren Suriyelilerin bazı şehirlerimizde kayda değer değişimlerin yaşanmasına sebep olduğu ortaya konmuștur. Talep artışından dolayı enflasyonun yükseliși, kayıt dışı çalışan kesimin ucuz iş gücü oluşturması ve firmalar arasında haksız rekabetin meydana gelmesi gibi birçok olumsuz sonuç doğurmuștur. Diğer taraftan yabancı sermayeli şirketler arasında Suriye kaynaklı şirketlerin oranının artışta olması ekonomimiz açısından bir firsat olarak görülmektedir (Sayın vd.,2016:9-10).

2017 yılında kamusal mallar teorisi üzerine yapılan çalıșmaya göre; zor durumdaki Suriyelilere açık kapı politikası uygulayan Türkiye, Lübnan, Mısır gibi ülkeler sağlık, eğitim, gıda ve barınma gibi kamusal mal ve hizmet üretimini gerçekleştirerek kendilerine düşen görevi yerine getirmiştir. Fakat her ülke bunu gerçekleştirmeyerek bedavacılık sorununun bu konuda da ortaya çıkmasına neden olmuştur. Küresel çapta tüm ülkelerin bu maliyetlere katılması beklenirken çoğunlukla göç alan ülkenin sırtına yük binmiştir ve göçün ortaya çıkarabileceği sorunların artmasına neden olmuştur. Sonuç olarak tüm ülkelerin bu maliyetlere katılması ve kısa sürede bu sorunun ortadan kalması beklenmektedir (Teyyare ve Yazıcı, 2017:429-449).

Ülkemizde göçün ekonomik etkileri üzerine yapılmış olan bazı çalışmalar ve sonuçları aşağıdaki tabloda yer almaktadır.

Tablo 8: Yapılmıș Benzer Çalıșmalar

\begin{tabular}{|c|c|c|c|}
\hline Çalışmanın Yazarı & $\begin{array}{c}\text { Çalışmanın } \\
\text { Yılı }\end{array}$ & $\begin{array}{c}\text { Kullanılan Analiz } \\
\text { Yöntemi }\end{array}$ & Elde Edilen Sonuçlar \\
\hline Paksoy v.d. & 2015 & $\begin{array}{c}\text { Spss Crosstab } \\
\text { Yöntemi }\end{array}$ & $\begin{array}{l}\text { Suriyelilerin kayıt dışı çalıștığı, ucuz } \\
\text { işgücü oluşturmasından dolayı işsizlik } \\
\text { oranını artırdığı sonuçlarına ulașılmıştır. }\end{array}$ \\
\hline Memiş & 2015 & $\begin{array}{l}\text { SpssCrosstab } \\
\text { Yöntemi }\end{array}$ & $\begin{array}{l}\text { Suriyelilere yapılan yardımların yeterli } \\
\text { olduğu ve işsizlik oranlarını artırdığı } \\
\text { sonucuna varılmıștır. }\end{array}$ \\
\hline Siverekli ve Ertuğrul & 2016 & $\begin{array}{l}\text { Spss Kruskalwallis, } \\
\text { Mann Whitney U testi } \\
\text { (Nonparametrik) }\end{array}$ & $\begin{array}{l}\text { Suriyelilere yapılan harcamaların vergi } \\
\text { kaybı ve kaçakçılığına neden olabileceği, } \\
\text { vergi yükünü artıracağı, toplumun ödediği } \\
\text { vergilerle ödendiği müddetçe de adaleti } \\
\text { bozucu olacağı tespit edilmiştir. }\end{array}$ \\
\hline
\end{tabular}

\section{DENIZLII'DE YASSAYAN GEÇİCI KORUMA ALTINDAKI SURIYELIILERİN DENIZLİ EKONOMISINE ETKISII ÜZERINE BÍR ARAŞTIRMA}

\subsection{Araştırmanın Amacı}

$\mathrm{Bu}$ araştırmanın amacl, Mart 2011'de Suriye'de çıkan çatışmanın giderek büyümesi sonucunda ülkelerini terk edip Denizli iline sığınan geçici koruma altındaki Suriyelilerin Denizli ekonomisine etkilerini saptamayı hedeflemektedir. Çalışmamızda, artmakta olan Suriyeli sayısının vatandaşımızı ekonomik açıdan ne yönde etkilediği araştırılmıştır. Elde edilecek sonuçlar sayesinde Denizli ekonomisini etkileyen 


\section{Ö. ÖZPENÇE - E. ÇELIK}

olumlu ve olumsuz durumlar ortaya konularak "nasıl önlem alabiliriz", "nasıl daha iyi bir ekonomiye sahip olabiliriz" sorusuna cevaplar aranmıștır..

\subsection{Araştırmanın Kapsamı ve Yöntemi}

Araştırmamızda Denizli'de ikamet eden 18 yaşından büyük 400 kişi için belirlenmiş olan sorular uygulanarak veriler elde edilmiştir. Hazırlanan anket sorularına cevaplar yüz yüze anket yoluyla elde edilmiştir ve "Kolayda örneklem" yöntemi kullanılmıştır. 19 Mart 2019'da başlayan anket uygulamamı 6 Nisan'da sonlandırılmıștır. Elde edilen verilerle SPSS analizi yapılmıştır.

Araştırma sonucunda "Geçici Koruma Altındaki Suriyelilerin Denizli Ekonomisine Etkisi" anketi geliştirilmiştir. Anket soruları hazırlanırken Paksoy vd. (2015), Memiş (2015), Siverekli ve Ertuğrul (2016)'da yapılan benzer çalışmalarda geliştirilen sorulardan yararlanılmıştır. Bazı sorular ise literatür taraması sonucunda tarafımızca hazırlanmıștır. 5 katılımciya uygulanan ön test sonucunda bazı sorular yeniden düzenlenerek anket son şeklini almıştır. Anketimizin ilk 5 sorusu yanıtlayan kişinin demografik bilgilerini, diğer 4 soru Suriyelilere ev ve işyeri kiralama durumunu, katılımcının çevresinde Suriyelilere ev ve iş yeri kiralayan olup olmadığ $ı$ ve yanında veya etrafında Suriyeli çalıştıran olup olmadığını öğrenerek yanıtlayanı tanımaya yönelik toplam 9 soru içermektedir. Diğer kısımlarda ise Suriyelilerle ilişkilendirilebilecek vergi algısı, kamu harcamaları artışı, kalabalıklaşma maliyeti, kayıt dışılık ve işsizlik, çalışma hayatına katılımları, gayrimenkul fiyatlarına etki, ekonomiye etki, yardımların yeterliliği ve enflasyona etki olmak üzere alt kollarıyla beraber toplam 21 soru vardır.

Anket verilerinin analiz ve yorumlanması evresinde SPSS 21.0 programı kullanılmıştır. Bulunan bulguların değerlendirme aşamasında verilerin ağırlıklı ortalama frekans analizleri, $\mathrm{T}$ testi ve Anova testi yapılmıştır.

Verilerin normal dağılım gösterip göstermediği analiz edildikten sonra eğer normal dağıldığı sonucuna varılıyorsa parametrik testler kullanılır. Normal dağılım göstermediği takdirde ise nonparametrik testler kullanılır. Fakat nonparametrik testlerin sonucu parametrik testlerin sonucu kadar güven vermemektedir. Çalıșmamızda verilerin normal dağıldığı sonucuna ulaşılmıştır. $\mathrm{Bu}$ nedenle de parametrik testler yapılmıştır. Parametrik testlerden biri olan Anova 3 veya daha fazla grubun ortalamaları arasında anlamlı bir farklılık olup olmadığını ölçmek için yapılır. Diğer parametrik testlerden biri ise $\mathrm{t}$ testidir. T testi bağımsız iki grup arasında anlamlı bir farklılık olup olmadığını incelemek için yapılır (Akbolat; Tonta, 3-5).

Araştırmada kullanılan ölçeğin güvenirliği ölçülmüş ve demografik sorular dikkate alınmadığında, ülkemizde yaşayan Suriyelilerin neden olduğu olumsuz vergi algısı 3 soru ile test edilerek bu sorulara ilişkin iç tutarlılık katsayısı (Cronbach's Alpha) 0,799 olarak bulunmuştur. Kamu harcamalarının artışına etkisi 4 soru ile ölçülmüştür ve iç tutarlılık katsayısı (Cronbach's Alpha) 0,853 olarak bulunurken kayıt dışılığa ve işsizliğe etkisi 4 soru ile ölçülmüştür. İç tutarlılık katsayısı (Cronbach's Alpha) 0,885 olarak bulunmuştur.

Tablo 9: Anketi Oluşturan Boyutun Madde Sayısı, Cronbach's Alpha Değeri

\begin{tabular}{|c|c|c|}
\hline Boyut & $\begin{array}{c}\text { Boyutun } \\
\text { Madde } \\
\text { Sayısı }\end{array}$ & $\begin{array}{c}\text { Cronbach's } \\
\text { Alpha }\end{array}$ \\
\hline Olumsuz Vergi Algısı & 3 & 0,799 \\
\hline Kamu harcamaları Artışı & 4 & 0,853 \\
\hline Kayıt dıșlık ve ișsizlik & 4 & 0,885 \\
\hline
\end{tabular}

\subsection{Araştırmanın Bulguları}

\subsubsection{Katılımcıların Demografik Yapısına İlişkin Bulgular}

Araștırmamıza katılanların demografik özelliklerinin belirlenmesine ilişkin sorulara verilen cevaplar aşağıda yer alan Tablo 10 'da gösterilmiştir. Cinsiyet dağılımı göz önünde bulundurulduğunda katılan 400 kişinin büyük bir kısmının erkek katılımcılardan oluştuğu görülmektedir. Çalışmaya katılanların çoğunluğu 30 yaş ve altı genç katılımcılardan oluşmaktadır. Katılımcıların eğitim durumları 
iki gruba ayrıldığında ise lise ve daha alt seviyede olanların yüzdesinin daha fazla olduğu görülmektedir. Katılımcılarımızın meslek dağılımları incelendiğinde esnaf ve iş adamından oluşan kesimin çoğunlukta olduğu tespit edilmiştir. Katılımcıların büyük kısmının çalışan kesimden oluştuğu ve çoğunluğun evli olduğu görülmektedir.

Tablo 10: Ankete Katılanların Demografik Özellikleri

\begin{tabular}{|c|c|c|c|c|c|}
\hline Cinsiyet & $\mathbf{N}$ & $\%$ & $\begin{array}{c}\text { Eğitim } \\
\text { Durumu }\end{array}$ & $\mathbf{N}$ & $\%$ \\
\hline Kadın & 133 & 33,3 & İlköğretim & 96 & 24 \\
\hline Erkek & 267 & 66,8 & Lise & 113 & 28,3 \\
\hline Yaş Aralığı & $\mathbf{N}$ & $\%$ & Üniversite & 181 & 45,3 \\
\hline $18-30$ & 170 & 42,5 & Yüksek Lisans & 7 & 1,8 \\
\hline $31-40$ & 89 & 22,3 & Doktora & 3 & 0,8 \\
\hline $41-50$ & 66 & 16,5 & $\begin{array}{c}\text { Eğitim } \\
\text { Seviyesi }\end{array}$ & $\mathbf{N}$ & $\%$ \\
\hline $\begin{array}{l}51 \text { yaş ve } \\
\text { üzeri }\end{array}$ & 75 & 18,8 & $\begin{array}{l}\text { Lise ve daha } \\
\text { alt seviye }\end{array}$ & 209 & 52,3 \\
\hline $\begin{array}{c}\text { Meslek } \\
\text { Dağılımı } \\
\end{array}$ & $\overline{\mathbf{N}}$ & $\%$ & $\begin{array}{l}\text { Lise ve daha } \\
\text { üst seviye }\end{array}$ & 191 & 47,8 \\
\hline $\begin{array}{l}\text { Esnaf-İş } \\
\text { adamı }\end{array}$ & 157 & 39,3 & $\begin{array}{l}\text { Çalışma } \\
\text { Durumu }\end{array}$ & $\mathbf{N}$ & $\%$ \\
\hline $\begin{array}{l}\text { Memur- } \\
\text { Masabaşı } \\
\text { çalıșan }\end{array}$ & 68 & 17 & Çalışan & 283 & 70,8 \\
\hline $\begin{array}{l}\text { İşçi-Bedenen } \\
\text { çalışan }\end{array}$ & 57 & 14,3 & Çalışmayan & 63 & 15,8 \\
\hline $\begin{array}{l}\text { Çiftçi- } \\
\text { Hayvancılık }\end{array}$ & 1 & 0,3 & Öğrenci & 54 & 13,5 \\
\hline İşsiz & 34 & 8,5 & $\begin{array}{l}\text { Medeni } \\
\text { Durum }\end{array}$ & $\mathbf{N}$ & $\%$ \\
\hline Emekli & 29 & 7,3 & Evli & 224 & 56 \\
\hline Öğrenci & 54 & 13,5 & Bekar & 176 & 44 \\
\hline
\end{tabular}

\subsection{2. Ölçülen Değişkenlerin Genel Ortalamaları ve Farklılık Analizi Sonuçları}

Ölçülen boyutların ortalamaları alındığında, Suriyelilerin vergi algısını olumsuz etkilemesi düşüncesine katılımın 3,85 ortalama ile yüksek olduğu tespit edilmiștir. Geçici koruma altındaki Suriyelilerden dolayı yüksek bir olumsuz vergi algısının oluştuğu sonucuna varılmıştır.

Kamu harcamalarının artışına neden olma durumuna katılım ise 4,04 ortalama ile yüksek bir düzeyde belirlenmiştir. Böylece Denizli'deki katılımclar Suriyelilerin kamu harcamalarının artışında önemli bir unsur olduğunu vurgulamışlardır.

Diğer bir boyut olan kayıt dışılığa ve işsizliğe neden olma durumuna katılımı 4,28 ortalama ile yüksek olduğu sonucuna ulaşılmıştır. Elde edilen yüksek ortalama ile Denizli'de yaşayan Suriyelilerin, Denizli'de kayıt dışılığ çalıştığı işlerde daha ucuza çalışarak işsizlik oranını da arttırdığı sonucuna varılmıștır.

Katılımcılar, Suriyelilerin ev-iş yeri kiralarını artırma, enflasyonun artmasına neden olma durumlarına orta düzeyde bir algıyla karşılık vermiş̧lerdir.

Tablo 11: Ölçülen Değişkenlerin Genel Ortalamaları

\begin{tabular}{|l|c|c|}
\hline Değiş̧enler & $\begin{array}{c}\text { Genel } \\
\text { Ortalamalar }\end{array}$ & Düzey \\
\hline $\begin{array}{l}\text { Suriyelilerin Vergi Algısını } \\
\text { Olumsuz Etkilemesi }\end{array}$ & 3,85 & Yüksek \\
\hline $\begin{array}{l}\text { Kamu Harcamalarının } \\
\text { Artışına Neden Olma } \\
\text { Durumu }\end{array}$ & 4,04 & Yüksek \\
\hline $\begin{array}{l}\text { Kayıt dışılığa ve İşsizliğe } \\
\text { Neden Olma Durumları }\end{array}$ & 4,28 & Yüksek \\
\hline $\begin{array}{l}\text { Ev ve İşyeri Kiralarını } \\
\text { Arttırma Durumu }\end{array}$ & 3,28 & Orta \\
\hline $\begin{array}{l}\text { Ekonomiyi Olumlu } \\
\text { Etkileme Durumu }\end{array}$ & 1,74 & Düşük \\
\hline $\begin{array}{l}\text { Suriyelilere Yapılan } \\
\text { Yardımların Yeterliliği }\end{array}$ & 4,20 & Yüksek \\
\hline $\begin{array}{l}\text { Enflasyonun Artmasına } \\
\text { Neden Olma Durumu }\end{array}$ & 3,43 & Orta \\
\hline $\begin{array}{l}\text { Suriyelilerin Çalışma } \\
\text { Hayatına Katılımları }\end{array}$ & 2,45 & Orta \\
\hline
\end{tabular}

Suriyelilere yapılan yardımların yeterliliği boyutunun ortalaması 4,20 ile yüksek düzeyde belirlenmiștir. Buna göre Denizli'deki katılımclar Suriyelilere yapılan yardımların yüksek oranda yeterli olduğunu savunmuşlardır.

Suriyelilerin çalışma hayatına katılımları 2,45 ortalama ile orta seviyede olduğu tespit edilmiştir. Katılımcılar Suriyelilerin çalışma hayatına katılımlarını orta seviyede desteklemișlerdir.

Ölçülen boyutların ortalamaları dikkate alındığında katılımcılar, Suriyelilerin vergi algısını olumsuz etkilediğini, kamu 


\section{Ö. ÖZPENÇE - E. ÇELIK}

harcamalarını artırdığını, özelliklede kayıt dışılığa ve işsizliğe neden olduklarını ve Suriyelilere yapılan yardımların yeterliliği konusunda yüksek bir algıya sahipken ekonomiyi ise olumlu yönde etkilemediklerini savunmuşlardır. Katılımcılar, Suriyelilerin ev ve iş yeri kiralarını artırma, enflasyonu artırma ve çalışma hayatına katılımlarının desteklenmesi konularına ise orta düzeyde bir algıyla karşılık vermişlerdir.

Tablo 12: Ortalamalar ve Düzeyleri

\begin{tabular}{|c|c|}
\hline Ortalamalar & Düzey \\
\hline $1-2.33$ & Düşük \\
\hline $2.34-3.66$ & Orta \\
\hline $3.67-5.0$ & Yüksek \\
\hline
\end{tabular}

Tablo 13: Cinsiyete Göre Karşılaștırma Sonuçları

\begin{tabular}{|c|c|c|c|c|}
\hline & & $\mathbf{N}$ & Ort. & $\mathbf{P}$ \\
\hline $\begin{array}{l}\text { Suriyelilerin } \\
\text { Neden Olduğu } \\
\text { Olumsuz Vergi } \\
\text { Algısı }\end{array}$ & $\begin{array}{l}\text { Kadın } \\
\text { Erkek }\end{array}$ & $\begin{array}{l}133 \\
267\end{array}$ & $\begin{array}{l}3,89 \\
3,83\end{array}$ & $0,627>0,05$ \\
\hline $\begin{array}{l}\text { Kamu } \\
\text { Harcamalarının } \\
\text { Artışına Neden } \\
\text { Olma Durumu }\end{array}$ & $\begin{array}{l}\text { Kadın } \\
\text { Erkek }\end{array}$ & $\begin{array}{l}133 \\
267\end{array}$ & $\begin{array}{l}3,97 \\
4,07\end{array}$ & $0,308>0,05$ \\
\hline $\begin{array}{l}\text { Kayıt dışılığa ve } \\
\text { İşsizliğe Neden } \\
\text { Olma Durumları }\end{array}$ & $\begin{array}{l}\text { Kadın } \\
\text { Erkek }\end{array}$ & $\begin{array}{l}133 \\
267\end{array}$ & $\begin{array}{l}4,15 \\
4,34\end{array}$ & $0,043<\mathbf{0 , 0 5}$ \\
\hline $\begin{array}{l}\text { Ev ve İşyeri } \\
\text { Kiralarını } \\
\text { Arttırma } \\
\text { Durumu }\end{array}$ & $\begin{array}{l}\text { Kadın } \\
\text { Erkek }\end{array}$ & $\begin{array}{l}133 \\
267\end{array}$ & $\begin{array}{l}3,21 \\
3,31\end{array}$ & $0,432>0,05$ \\
\hline $\begin{array}{l}\text { Ekonomiyi } \\
\text { Olumlu Etkileme } \\
\text { Durumu }\end{array}$ & $\begin{array}{l}\text { Kadın } \\
\text { Erkek }\end{array}$ & $\begin{array}{l}133 \\
267\end{array}$ & $\begin{array}{l}1,74 \\
1,73\end{array}$ & $0,934>0,05$ \\
\hline $\begin{array}{l}\text { Suriyelilere } \\
\text { Yapılan } \\
\text { Yardımların } \\
\text { Yeterliliği }\end{array}$ & Erkek & 267 & 4,22 & $0,439>0,05$ \\
\hline $\begin{array}{l}\text { Enflasyonun } \\
\text { Artmasına Neden } \\
\text { Olma Durumu }\end{array}$ & $\begin{array}{l}\text { Kadın } \\
\text { Erkek }\end{array}$ & $\begin{array}{l}133 \\
267\end{array}$ & $\begin{array}{l}3,35 \\
3,47\end{array}$ & $0,385>0,05$ \\
\hline
\end{tabular}

Tablo 13'de kadın ve erkekler arasında Suriyelilerin kayıt dışılığa ve işsizliğe neden olma durumları açısından farklılık olup olmadığı $\mathrm{t}$ testi uygulanarak test edilmiștir. Katılımcı kadın ve erkeklerin kayıt dışılığa ve işsizliğe neden olma durumları arasında anlamlı bir farklılık olduğu $[\mathrm{p}(0,043)<0,05]$ tespit edilmiștir. Dolayısıyla erkekler kadınlara oranla Suriyelilerin kayıt dıșılığı ve işsizliği artırdığını daha fazla savunmuşlardır. Kadınlar ise kayıt dışılığın ve işsizliğin artmasında Suriyelilerin etkisinin daha az olduğunu belirtmişlerdir. Ölçülen diğer değişkenler arasında ise istatistiksel olarak anlamlı bir farklılık olmadığı sonucuna ulaşılmıştır.

Tablo 14: Çalışıp Çalışmama Durumuna Göre Karşılaştırma Sonuçları

\begin{tabular}{|c|c|c|c|c|}
\hline & \begin{tabular}{|l|} 
Çalışıp \\
Çalışmama \\
Durumu \\
\end{tabular} & $\mathbf{N}$ & Ort. & $\mathbf{P}$ \\
\hline $\begin{array}{l}\text { Suriyelilerin } \\
\text { Neden Olduğu } \\
\text { Olumsuz Vergi } \\
\text { Algısı }\end{array}$ & $\begin{array}{l}\text { Çalıșan } \\
\text { Çalışmayan } \\
\text { Öğrenci } \\
\text { Toplam }\end{array}$ & \begin{tabular}{|c|}
283 \\
63 \\
54 \\
400
\end{tabular} & $\begin{array}{l}3,85 \\
3,82 \\
3,87 \\
3,85\end{array}$ & $0,968>0,05$ \\
\hline \begin{tabular}{|l|} 
Kamu \\
Harcamalarının \\
Artışına Neden \\
Olma Durumu
\end{tabular} & $\begin{array}{l}\text { Çalıșan } \\
\text { Çalışmayan } \\
\text { Öğrenci } \\
\text { Toplam }\end{array}$ & $\begin{array}{c}283 \\
63 \\
54 \\
400\end{array}$ & $\begin{array}{l}4,02 \\
4,17 \\
3,97 \\
4,04\end{array}$ & $0,396>0,05$ \\
\hline $\begin{array}{l}\text { Kayıt dışılığa ve } \\
\text { İşsizliğe Neden } \\
\text { Olma } \\
\text { Durumları }\end{array}$ & $\begin{array}{l}\text { Çalış̧an } \\
\text { Çalışmayan } \\
\text { Ögrenci } \\
\text { Toplam }\end{array}$ & $\begin{array}{c}283 \\
63 \\
54 \\
400\end{array}$ & $\begin{array}{l}4,33 \\
4,17 \\
4,13 \\
4,28\end{array}$ & $0,156>0,05$ \\
\hline $\begin{array}{l}\text { Ev ve İşyeri } \\
\text { Kiralarını } \\
\text { Arttırma } \\
\text { Durumu }\end{array}$ & $\begin{array}{l}\text { Çalışan } \\
\text { Çalışmayan } \\
\text { Öğrenci } \\
\text { Toplam }\end{array}$ & $\begin{array}{c}283 \\
63 \\
54 \\
400\end{array}$ & $\begin{array}{l}3,26 \\
3,07 \\
3,63 \\
3,28\end{array}$ & $0,042<\mathbf{0 , 0 5}$ \\
\hline \begin{tabular}{|l|} 
Ekonomiyi \\
Olumlu \\
Etkileme \\
Durumu
\end{tabular} & $\begin{array}{l}\text { Çalış̧an } \\
\text { Çalışmayan } \\
\text { Ögrenci } \\
\text { Toplam }\end{array}$ & \begin{tabular}{|c|}
283 \\
63 \\
54 \\
400
\end{tabular} & $\begin{array}{l}1,74 \\
1,71 \\
1,77 \\
1,74\end{array}$ & $0,941>0,05$ \\
\hline $\begin{array}{l}\text { Suriyelilere } \\
\text { Yapılan } \\
\text { Yardımların } \\
\text { Yeterliliği }\end{array}$ & $\begin{array}{l}\text { Çalıșan } \\
\text { Çalışmayan } \\
\text { Ö̆ğrenci } \\
\text { Toplam }\end{array}$ & $\begin{array}{c}283 \\
63 \\
54 \\
400\end{array}$ & $\begin{array}{c}4,21 \\
4,3 \\
3,98 \\
4,2\end{array}$ & $0,252>0,05$ \\
\hline \begin{tabular}{|l|} 
Enflasyonun \\
Artmasına \\
Neden Olma \\
Durumu
\end{tabular} & $\begin{array}{l}\text { Çalıșan } \\
\text { Çalışmayan } \\
\text { Ögrrenci } \\
\text { Toplam }\end{array}$ & $\begin{array}{c}283 \\
63 \\
54 \\
400\end{array}$ & $\begin{array}{l}3,46 \\
3,46 \\
3,24 \\
3,43\end{array}$ & $0,550>0,05$ \\
\hline
\end{tabular}

Tablo 14'te gösterildiği gibi, katılımcıların çalışıp çalışmama durumu ile ev ve işyeri kiralarını artırma durumu açısından farklılık olup olmadığını test etmek amacı ile anova testi uygulanmıştır. Katılımcılar 3 gruba ayrılmıştır ve ev ve işyeri kiralarını artırma 
düzeyleri arasında anlamlı bir farklılık olduğu $[\mathrm{p}(0,042)<0,05]$ sonucuna ulaşılmıştır. $\mathrm{Bu}$ doğrultuda, öğrenciler diğer iki gruba göre (çalışan, çalışmayan) Suriyelilerin ev ve iş yeri kiralarını daha fazla artırdığını belirtmişlerdir. Sonuç olarak bu durumdan kaynaklı ev kirası artışı öğrenci kesimini daha fazla etkilemiștir.

Tablo 15: Eğitim Düzeyine Göre Karşıllaştırma Sonuçları

\begin{tabular}{|c|c|c|c|c|}
\hline & Eğitim Düzeyi & $\mathbf{N}$ & Ort. & $\mathbf{P}$ \\
\hline $\begin{array}{l}\text { Suriyelilerin } \\
\text { Neden Olduğu } \\
\text { Olumsuz Vergi } \\
\text { Algısı }\end{array}$ & $\begin{array}{l}\text { Lise ve daha alt } \\
\text { seviye } \\
\text { Lisans ve daha } \\
\text { üst seviye }\end{array}$ & 209 & 3,86 & $0,890>0,05$ \\
\hline $\begin{array}{l}\text { Kamu } \\
\text { Harcamalarının } \\
\text { Artışına Neden } \\
\text { Olma Durumu }\end{array}$ & $\begin{array}{l}\text { Lise ve daha alt } \\
\text { seviye } \\
\text { Lisans ve daha } \\
\text { üst seviye }\end{array}$ & 209 & 4,08 & $0,384>0,05$ \\
\hline $\begin{array}{l}\text { Kayıt dışılığa } \\
\text { ve İşsizliğe } \\
\text { Neden Olma } \\
\text { Durumları }\end{array}$ & $\begin{array}{l}\text { Lise ve daha alt } \\
\text { seviye } \\
\text { Lisans ve daha } \\
\text { üst seviye }\end{array}$ & 209 & 4,27 & $0,976>0,05$ \\
\hline $\begin{array}{l}\text { Ev ve İşyeri } \\
\text { Kiralarını } \\
\text { Arttırma } \\
\text { Durumu }\end{array}$ & $\begin{array}{l}\text { Lise ve daha alt } \\
\text { seviye } \\
\text { Lisans ve daha } \\
\text { üst seviye }\end{array}$ & 209 & 3,38 & $0,115>0,05$ \\
\hline $\begin{array}{l}\text { Ekonomiyi } \\
\text { Olumlu } \\
\text { Etkileme } \\
\text { Durumu }\end{array}$ & $\begin{array}{l}\text { Lise ve daha alt } \\
\text { seviye } \\
\text { Lisans ve daha } \\
\text { üst seviye }\end{array}$ & 209 & 1,68 & $0,206>0,05$ \\
\hline $\begin{array}{l}\text { Suriyelilere } \\
\text { Yapılan } \\
\text { Yardımların } \\
\text { Yeterliliği }\end{array}$ & $\begin{array}{l}\text { Lise ve daha alt } \\
\text { seviye } \\
\text { Lisans ve daha } \\
\text { üst seviye }\end{array}$ & 209 & 3,98 & $0,000<\mathbf{0 , 0 5}$ \\
\hline $\begin{array}{l}\text { Enflasyonun } \\
\text { Artmasına } \\
\text { Neden Olma } \\
\text { Durumu }\end{array}$ & $\begin{array}{l}\text { Lise ve daha alt } \\
\text { seviye } \\
\text { Lisans ve daha } \\
\text { üst seviye }\end{array}$ & 209 & 3,48 & $0,458>0,05$ \\
\hline
\end{tabular}

Tablo 15'te gösterildiği gibi, katılımclların eğitim düzeyleri ile Suriyelilere yapılan yardımların yeterliliği açısından farklılık olup olmadığını test etmek amacı ile $t$ testi uygulanmıştır. İki gruba ayrılan katılımcılar ile yapılan yardımların yeterliliği arasında anlamlı bir farklılık olduğu $[p(0,000)<0,05]$ sonucuna ulaşılmıştır. Bu doğrultuda eğitim seviyesi düșük olanlar, Suriyelilere yapılan yardımların yeterli olduğunu eğitim seviyesi yüksek olanlara oranla daha fazla savunmuşlardır. Ölçülen diğer değişkenler arasında ise istatistiksel olarak anlamlı bir farklılık olmadığı sonucuna ulaşılmıştır.

Tablo 16: Suriyelilerin Çalışma Hayatına Katılımlarına Yönelik Farklılık Analizi

\begin{tabular}{|c|c|c|c|c|c|}
\hline \multirow{5}{*}{ 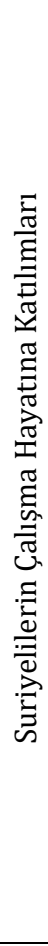 } & & & $\mathrm{N}$ & Ort. & $\mathrm{P}$ \\
\hline & Cinsiyet & $\begin{array}{l}\text { Kadın } \\
\text { Erkek }\end{array}$ & $\begin{array}{l}133 \\
267\end{array}$ & $\begin{array}{l}2,77 \\
2,29\end{array}$ & \begin{tabular}{|l}
$0,004<$ \\
$\mathbf{0 , 0 5}$
\end{tabular} \\
\hline & $\begin{array}{l}\text { Eğitim } \\
\text { Düzeyi }\end{array}$ & $\begin{array}{l}\text { Lise ve } \\
\text { daha alt } \\
\text { seviye } \\
\text { Lisans ve } \\
\text { daha üst } \\
\text { seviye }\end{array}$ & $\begin{array}{l}209 \\
191\end{array}$ & $\begin{array}{l}2,27 \\
2,65\end{array}$ & $\begin{array}{l}0,018< \\
\mathbf{0 , 0 5}\end{array}$ \\
\hline & $\begin{array}{l}\text { Yaş } \\
\text { Aralığg }\end{array}$ & $\begin{array}{l}18-30 \\
31-40 \\
41-50 \\
51 \text { yaş ve } \\
\text { üzeri } \\
\text { Toplam } \\
\end{array}$ & $\begin{array}{l}170 \\
89 \\
66 \\
75 \\
400 \\
\end{array}$ & $\begin{array}{l}2,66 \\
2,34 \\
2,29 \\
2,27 \\
2,45 \\
\end{array}$ & $\begin{array}{l}0,166> \\
0,05\end{array}$ \\
\hline & $\begin{array}{l}\text { Çalıșma } \\
\text { Durumu }\end{array}$ & $\begin{array}{l}\text { Çalışan } \\
\text { Çalışmaya } \\
\text { n } \\
\text { Öğrenci } \\
\text { Toplam }\end{array}$ & \begin{tabular}{|l}
283 \\
63 \\
54 \\
400 \\
\end{tabular} & $\begin{array}{l}2,38 \\
2,49 \\
2,78 \\
2,45 \\
\end{array}$ & $\begin{array}{l}0,238> \\
0,05\end{array}$ \\
\hline
\end{tabular}

Tablo 16'da katılımcıların cinsiyeti, eğitim düzeyi, yaş aralığı ve çalışma durumları dikkate alınarak Suriyelilerin çalıșma hayatına katılımları açısından farklılık olup olmadığını test etmek amacı ile t testi (cinsiyet ve eğitim düzeyi) ve anova testi (yaş aralığı ve çalışma durumu) yapılmıştır. T testi sonuçlarına göre; kadın ve erkeklerin Suriyelilerin çalışma hayatına katılım düzeyleri arasında anlamlı bir farklılık olduğu $[p(0,004)<0,05]$ tespit edilmiştir. $\mathrm{Bu}$ doğrultuda kadınlar, Suriyelilerin çalışma hayatına katılımlarını erkeklere nazaran daha çok desteklemektedir. Erkekler ise Suriyelilerin çalışma hayatına katılımlarını kadınlara oranla daha az desteklemektedirler. Eğitim düzeyleri ve Suriyelilerin çalıșma hayatına katılımları açısından incelendiğinde anlamlı bir farklılık olduğu $\quad[p(0,018)<0,05]$ tespit edilmiştir. Dolayısıyla eğitim düzeyi yüksek olan kesim 


\section{Ö. ÖZPENÇE - E. ÇELIK}

(lisans ve daha üst seviye) eğitim seviyesi düşük olan kesime (lise ve daha alt seviye) göre Suriyelilerin çalışma hayatına katılımlarına daha olumlu yaklaşmaktadır. Diğer durumlarda ise anlamlı bir farklılık olmadığı tespit edilmiştir.

Tablo 17: Suriyelilerin Kalabalıklaşma Maliyetine (Nüfusun sayısı arttıkça sunulan hizmet kalitesinin düşmesi) Neden Olma Durumlarına Yönelik Farklılık Analizi

\begin{tabular}{|c|c|c|c|c|c|}
\hline \multirow{15}{*}{ 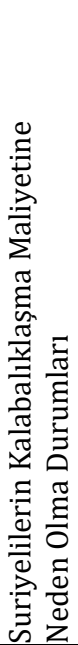 } & & & $\mathrm{N}$ & Ort. & $\mathrm{P}$ \\
\hline & \multirow{3}{*}{ Cinsiyet } & Kadın & 133 & 3,81 & \multirow[b]{2}{*}{$0,571>0,05$} \\
\hline & & Erkek & 267 & 3,72 & \\
\hline & & & & & \\
\hline & \multirow[b]{2}{*}{$\begin{array}{l}\text { Ĕgitim } \\
\text { Düzeyi }\end{array}$} & $\begin{array}{l}\text { Lise ve daha alt } \\
\text { seviye }\end{array}$ & 209 & 3,63 & \multirow[b]{2}{*}{$0,088>0,05$} \\
\hline & & $\begin{array}{l}\text { Lisans ve daha } \\
\text { üst seviye }\end{array}$ & 191 & 3,88 & \\
\hline & \multirow{5}{*}{$\begin{array}{l}\text { Yaş } \\
\text { Aralığı }\end{array}$} & $18-30$ & 170 & 4,01 & \\
\hline & & $31-40$ & 89 & 3,54 & \\
\hline & & $41-50$ & 66 & 3,53 & $0,031<0,05$ \\
\hline & & 51 yaș ve üzeri & 75 & 3,63 & \\
\hline & & Toplam & 400 & 3,75 & \\
\hline & \multirow{4}{*}{$\begin{array}{l}\text { Çalıșma } \\
\text { Durumu }\end{array}$} & Çalışan & 283 & 3,69 & \\
\hline & & Çalışmayan & 63 & 3,62 & $0,024<0,05$ \\
\hline & & Öğrenci & 54 & 4,26 & \\
\hline & & Toplam & 400 & 3,75 & \\
\hline
\end{tabular}

Tablo 17'de katılımcların cinsiyeti, eğitim düzeyi, yaş aralığı ve çalışma durumları dikkate alınarak Suriyelilerin kalabalıklașma maliyetine neden olma durumu açısından farklılık olup olmadığını test etmek amacı ile $t$ testi (cinsiyet ve eğitim düzeyi) ve anova testi (yaş aralığı ve çalışma durumu) yapılmıştır. Anova testi sonuçlarına göre; katılımcılar yaş aralıklarına göre dörde ayrılmış olup kalabalıklaşma maliyetine neden olma durumları açısından anlamlı bir farklılık olduğu $[\mathrm{p}(0,031)<0,05]$ sonucuna ulaşılmıştır. Dolayısıyla 18-30 yaş aralığı, Suriyelilerin sayısı arttıkça sunulan hizmet kalitesinin düşmesi durumuna neden olduğunu diğer yaş aralıklarına göre daha fazla savunmaktadır. Diğer bir açıdan katılımcılar çalışan, çalışmayan ve öğrenci olarak sınıflandırılmış olup Suriyelilerin kalabalıklaşma maliyetine neden olma durumları açısından anlamlı bir farklılık olduğu $[\mathrm{p}(0,024)<0,05]$ tespit edilmiştir. $\mathrm{Bu}$ doğrultuda öğrenci kesim, Suriyelilerin sayısı arttıkça sunulan hizmet kalitesinin düşmesi durumuna neden olduğunu diğer kesime göre (çalışan, çalışmayan) daha fazla savunmaktadır. Diğer durumlarda ise anlamlı bir farklılık olmadığ tespit edilmiştir.

\section{SONUÇ}

Literatür taraması sonucunda Geçici Koruma Altındaki Suriyelilerin açıklanan veriler çerçevesinde kamu maliyesine yükünün 20112015 yılları arasında 6,8 milyar dolar yani 19,8 milyar TL olduğu bilinmektedir. Türkiye'deki Bakanlık ve diğer kamu kurumları tarafindan yapılan bu kamu harcamaları, Suriyeliler ülkemize göç etmemiş olsaydı eğer mali yük olarak mevcut olmayacaktı. Fakat kamu kurumları tarafından yapılan 19,8 milyar TL'lik kamu harcamalarının sadece 1 milyar 451 milyon TL'sinin açık bir şekilde kurumlar bazında açıklandığı diğer bölümünün ve harcama kalemlerinin açıklanmadığı görülmektedir. Suriyelilerin kamu harcamalarımızda yarattığ artış 2011-2015 yılları arasında 6,8 milyar dolar iken bu yıllar arasında dış kaynaklardan gelen ve yine kamu harcamaları için kullanılan tutar ise 417 milyon dolar olarak kayıtlara geçmiştir. Suriyeliler için yapılan iç kaynakların ve dış kaynakların harcamalarının toplamı bu yıllar arasında 7.158.250.458 ABD Doları olarak hesaplanmıştır.

Bununla birlikte hem Suriyeliler için hem de tüm yabancılar için uygulanan Şartlı Eğitim yardımı için 2017'de harcanan tutar 32 milyon iken 2018'de bu tutar yararlanan kişi sayısıyla beraber artış göstererek 175 milyona ulaşmıştır. Fakat bu harcamalar ülkemiz tarafından değil $\mathrm{AB}$ tarafından finanse edilmektedir. Diğer bir yardım türü olan yabancılara yönelik uygulanan Sosyal Uyum Yardım Programı da AB ve üyeleri tarafından finanse edilmektedir ve 2016 yılı için aktarılan kaynak 391.300 TL iken 2017'de 1.067 .000 ve 2018 'de 2.117.000 olmuştur. $\mathrm{Bu}$ veriler sayesinde ülkemiz ve $A B$ tarafından Suriyeliler için yeterli denebilecek düzeyde yardımların yapıldı̆̆ı görülmektedir. 
Suriyelilerin ülkemizdeki kayıt dışılığın artmasına etkisi düşünüldüğünde ve 2017 yılı verileri göz önünde bulundurulduğunda ülkemizde 3,5 milyonu aşkın Suriyeli yaşamasına rağmen sadece 20.966 Suriyelinin çalışma iznine sahip olması yürürlüğe giren çalışma izni uygulamasının tam olarak işlevini yerine getiremediğini ve kayıt dışılığın azalması yönünde yeterli olmadığını göstermektedir. Sadece 20.966 Suriyelinin çalışma iznine sahip olması hala birçok Suriyelinin kayıt dışı çalıştığını ve ülkemizdeki işsizliği de etkilediğini göstermektedir.

Araştırma sonuçlarına gelindiğinde ise, anket çalışmamıza katılan erkekler kadınlara nazaran Suriyelilerin kayıt dışılığı ve işsizliği artırdığını daha fazla savunmuştur. Aynı zamanda öğrenci kesim çalışan ve çalıșmayan diğer kesime göre Suriyelilerin ev ve iş yeri kiralarını arttırdığını ve kira artışlarını daha belirgin bir şekilde hissettiklerini belirtmişlerdir. Buna ek olarak, yaş aralıklarına göre 4 gruba ayrılan katılımcılardan 41-50 yaş aralığı diğer yaş aralıklarına göre Suriyelilerin ekonomiyi olumlu yönde etkilediğini daha fazla savunmuşlardır.

Araştırmamızın diğer bir tespiti ise, eğitim seviyesi düşük olanlar Suriyelilere yapılan yardımların yeterli olduğunu eğitim seviyesi yüksek olanlara oranla daha fazla savunmuşlardır. Katılımcıların eğitim seviyesi düştükçe yapılan yardımların yeterliliği konusundaki görüş birliği de artmaktadır. Eğitim seviyesi yüksek olanlar ise yardımlar konusunda daha esnek bir bakış açısına sahiptir. Ayrıca kadınlar, Suriyelilerin Denizli'de çalışma hayatına katılmalarını erkeklere nazaran daha fazla destekleyip bu konuda Suriyelilere daha ılımlı bir yaklaşımda bulunmuşlardır. Erkekler ise Suriyelilerin çalışma hayatına katılımları konusunda daha çekimser bir duruş sergilemişlerdir.

Kayıt dişılığı ve işsizliği artırma oranı ölçülen boyutlar arasından en yüksek orana sahip olmakla beraber katılımcllar; Suriyelilerin Denizli iş gücü piyasasında tekstil, inşaat ve diğer bazı ağır beden gücü isteyen sektörlerde kayıt dişı ve düşük ücretlerde çalıştırıldıklarını, bu durumunda yerli halkın iş bulurken zorluk çekmesine neden olduğunu belirtmişlerdir.

Suriyelilerin Denizli iş gücü piyasasında yer almaları ve çalışma hayatına katılımlarının desteklenip desteklenmemesi konusunda ise katılımcılar orta düzeyde bir fikir beyan ederek; katılımcıların belli bir kısmı çalışma hayatına katılmaları gerektiğini, yaşamlarını sürdürebilmek için buna gereksinim duyduklarını ve beden gücü isteyen bazı sektörlerde çalışarak iş gücü açığını kapatabileceklerini belirtmiştir. Katılımcıların diğer kısmı ise çalışma hayatına katılımlarının sağlanmaması gerektiğini çünkü genç nüfus arttıkça ve çalışma izni verildikçe kendi vatandaşımızın işsiz kalacağ korkularını dile getirmiştir. Dolayısıyla Suriyelilerin çalışma hayatına katılımları konusunda orta düzeyde bir fikir birliği mevcuttur. Bu durumu en çok destekleyen kesim ise kadınlar ve eğitim seviyesi yüksek olan kesimdir.

Genel olarak araştırmamızın sonuçlarına bakıldığında Suriyelilerin olumsuz bir vergi algısı olușturduğu, kamu harcamalarının artışında etkilerinin olduğu, kayıt dişılığı ve işsizliği yüksek oranda artırdığı sonucuna ulaşllırken ekonomiyi olumlu yönde etkileme durumunun da çok düşük olduğu sonuç olarak ekonomimizi olumlu yönde etkilemediği sonucuna varılmıştır.

Sonuç olarak kayıt dışı ve düşük ücretle çalıştırılan Suriyelilerin önüne geçilerek tedbirler alınmalı, oluşan haksız rekabet ortamı ortadan kaldırılmalıdır. Aynı zamanda işverenler bilinçlendirilerek özendirici destekler verilmeli, düşük ücret anlayışı ortadan kaldırılarak işsizlik oranının artışı engellenmelidir. 


\section{KAYNAKÇA}

AKBAȘ, S., ULUTAŞ ÜNLÜTÜRK Ç. (2018), "Küresel Fabrika Kentinin Görünmeyen İşçileri: Denizli İşgücü Piyasasında Suriyeli Göçmenler", Çalışma ve Toplum,188.

AKBOLAT M. Parametrik Testler, (Biyoistatistik), Sakarya Üniversitesi İșletme Fakültesi.

ANRIG, G. (2004). "The Century Foundation”, https://tcf.org/content/commentary/immig ration-jobs-and-the-american-economy (17.01.2018).

ASLANTÜRK,O., TUNÇ Y. (2018),“Türkiye'de Yabancıların Çalışma İzinleri: Suriyeliler Örneği", Ombudsman Akademik.

BUDAK, T., YÜZBAŞI, E., OKUMUŞ Y. S. "Suriye'deki İç Savaşın Etkileri", Bilgesam, 110.

Chmura Economics \&Analytics, (2012). "Economic Impact of Refugees in the Cleveland Area", ABD, 1-44.

CORNELIUS, J. M., BOSWELL, T., JENNIEIERMANN, S., BREUNER, C.W., RAMENOFSKY,M. (2013), "Contributions of Endocrinology to the Migration Life History of Birds", General and Comparative Endocrinology, Cilt:190, 47-60.

ÇAĞLAYAN, S. (2006), "Göç Kuramları, Göç ve Göçmen İlişkisi", Sosyal Bilimler Enstitüsü Dergisi (Illke), 67-91.

De Bel-Air Françoise (2016). "Migration Profile: Syria", Migration Policy Centre.

DINGLE, H., DRAKE, A. V. (2007), "What is Migration”, BioScience, 57/2, 113-121.

Erdoğan Murat, Ünver Can, (2015). “Türk İş Dünyasının Türkiye'deki Suriyeliler Konusundaki Görüş, Beklenti ve Önerileri" ,TÍSK 353, Ankara, 5-98.

Haran, (2016). "Roots Of The Syrian Crisis By VP Haran", IPCS 181.
International Federation of Red Cross and Red Crescent Societies, "The Phenomenon of Migration", http://www.ifrc.org/PageFiles/89397/the\% 20phenomenon\%20of\%20migration_TYPEF I_final_En. (12.11.2017).

International Organization for Migration, Migration and History.

İçişleri Bakanlığı Göç İdaresi Genel Müdürlüğü (2013). Yabancılar ve Uluslararası Koruma Kanunu, Ankara.

İçişleri Bakanlığı Göç İdaresi Genel Müdürlüğü (2019).

http://www.goc.gov.tr/icerik6/gecicikoruma_363_378_4713_icerik (20.04.2019).

İçişleri Bakanlığı Göç İdaresi Genel Müdürlüğü

http://www.goc.gov.tr/icerik6/avrupa-

birliginde-gecici

koruma_409_558_1096_icerik (10.06.2019).

KARKIN, V., YAZICI, Ö. (2015), "Arap Baharının Suriye'ye Yansıması ve Türkiye'ye Sığınan Mülteciler (Gaziantep Örneği)" , 21. Yüzyılda Eğitim ve Toplum, Cilt:4/12, 202203.

Maliye Bakanlığı (2018). 2017 Yılı Genel Faaliyet Raporu.

MEMIŞ, H. (2015), “İç Savaș Nedeniyle Kilis'te Yaşayan Suriyelilerin Oluşturduğu SosyoEkonomik Algllar Üzerine Bir Araştırma", Elektronik Sosyal Bilimler Dergisi, 14/52, 101-114.

Mültecilerin Hukuk Statüsüne İlişkin 1967 Protokolü, $\quad 1968$, https://www.goc.gov.tr/files/files/M\%C3\% 9CLTEC\%C4\%B0LER\%C4\%B0N\%20HUKUK \%20STAT\%C3\%9CS\%C3\%9CNE\%20\%C4\% B0L\%C4\%B0\%C5\%9EK\%C4\%B0N\%20196 7\%20PROTOKOL\%C3\%9C(1).pdf (04.07.2019). 
NASSAR, N. (2013), "What Caused Syria's Civil War?",

https://www.worldwatchmonitor.org/2013

/08/what-caused-syrias-civil-war/,

(28.02.2018).

PAKSOY, M. H., KOÇARSLAN, H., KILINÇ, E., TUNÇ A. (2015), "Suriyelilerin Ekonomik Etkisi: Kilis İli Örneği”, Birey ve Toplum, 5/9, 143-173.

POOT, J., COCHRANE, B. (2004), "Measuring the Economic Impact of Immigrattion: A Scoping Paper", Departman of Labour.

RAVENSTEIN, E. G. (1885), "Journal of the Statistical Society of London" Cilt:48, 167235.

SAYIN, Y., USANMAZ, A., ASLANGİRİ, F. (2016), "Uluslararası Göç Olgusu ve Yol Açtığı Etkiler: Suriye Göçü Örneği", KMÜ Sosyal ve Ekonomik Araştırmalar Dergisi, 18/31, 1-13.

SIVEREKLİ, E., ERTUĞRUL, G. H. (2016), "Misafirlikten Diasporaya Doğru: Suriyeli Sığınmacıların Vergi Algısı Üzerindeki Etkisine Yönelik Bir İnceleme", Yönetim Bilimleri Dergisi, 14/27, 491-518.

T.C. Aile, Calıșma ve Sosyal Hizmetler Bakanlığı (2017). Yabancıların Çalışma İzinleri 2017.

T.C. Aile, Çalıșma ve Sosyal Hizmetler Bakanlığı, (2018). "2018 Yllı Faaliyet Raporu", Ankara, 1-340.

T.C. Aile ve Sosyal Politikalar Bakanlığı, (2016). “2016 Yılı Faaliyet Raporu”, Ankara, 1-214.

TEYYARE, E., SAYANER, K. (2017), "Suriye İç Savaşı Sonrası Ortaya Çıkan Göç Hareketinin Kamusal Mallar Teorisi Çerçevesinde
Değerlendirilmesi", Bartın Üniversitesi İ.İ.B.F. Dergisi, 8/15, 429-454.

Tonta Yaşar, Varyans Analizi (ANOVA), Kovaryans Analizi (ANCOVA), Faktöriyel Anova, Çoklu Varyans Analizi (MANOVA), Hacettepe Üniversitesi Bilgi ve Belge Yönetimi.

TOPAL, A. (2015), "Geçici Koruma Yönetmeliği ve Türkiye'deki Suriyelilerin Hukuki Statüsü", İstanbul Medipol Üniversitesi Hukuk Fakültesi Dergisi 2, 5-22.

Türk Kızlay Göç Hizmetleri Direktörlüğü (2019). Suriye İnsani Yardım Operasyonu.

United Nations High Commissioner for Refugees (1992), Handbook on Procedures and Criteria for Determining Refugee Status under the 1951 Convention and the 1967 Protocol relating to the Status of Refugees, Geneva.

United Nations High Commissioner for Refugees the United Nations Refugees Agency (2010). Convention and Protocol Relating to the Status of Refugees, Geneva.

United Nations High Commissioner for Refugees the United Nations Refugees Agency, Syrian Refugees in Turkey Frequently Asked Questions, https://www.fluechtlingshilfe.ch/assets/hilf e/syrien/faq-syrians-in-turkeyenglish(14.03.2018).

WellCommunities, (2018). “Ortadoğu'dan Göçün Türkiye Üzerindeki Etkileri Raporu”, Antalya, 1-88.

21. Yüzyll Türkiye Enstitüsü. (2020). Geçici Korunan Suriyelilerin Türk Ekonomisine Etkileri. 